\title{
Perceptions of climate change risk to forest ecosystems and forest-based communities
}

\author{
by T.B. Williamson ${ }^{1,2}$, J.R. Parkins ${ }^{1}$ and B.L. McFarlane ${ }^{1}$
}

\begin{abstract}
Perception of risk or subjective risk is playing an increasingly important role in risk assessment. This paper describes a study that investigated perceptions of climate change risk to forest ecosystems and forest-based communities among a sample of Canadian forestry experts. Data were collected by questionnaire from participants at a climate change and forestry workshop, sponsored by the Canadian Climate Impacts and Adaptation Research Network Forest Sector and the McGregor Model Forest held in Prince George, British Columbia in February 2003. These forestry experts were somewhat concerned about the impacts of climate change, and they appeared unlikely to oppose strategies for preparing for and adapting to climate change. The respondents felt that the effects of climate change on forests and forest-based communities are not well understood by the general public or forest managers. They also felt that there is a relatively high level of uncertainty about the effects of climate change, especially with respect to forest-based communities. These results have important implications, including reinforcement of the need for greater awareness of climate change risks and for increased research and monitoring effort targeted at reducing levels of uncertainty about future impacts at local scales.
\end{abstract}

Key words: climate change, risk perceptions, forest ecosystems, forest-based communities

\section{RÉSUMÉ}

La perception du risque ou risque subjectif joue un rôle de plus en plus important au niveau de l'évaluation du risque. Cet article décrit une étude qui a porté sur les perceptions du risque associé aux changements climatiques touchant les écosystèmes forestiers et les communautés dépendantes des forêts parmi certains experts forestiers canadiens. Les données ont été recueillies au moyen d'un questionnaire complété par les participants d'un atelier sur les changements climatiques et la foresterie, commandité le Réseau canadien du secteur forestier sur les changements climatiques et les recherches d'adaptation ainsi que par la Forêt modèle de McGregor qui a eu lieu à Prince George, Colombie-Britannique, en février 2003. Ces experts forestiers étaient quelque peu inquiets des conséquences découlant des changements climatiques et ils ont semblé n'être vraisemblablement pas opposés aux stratégies de préparation et d'adaptation aux changements climatiques. Les personnes interrogées considèrent que les effets des changements climatiques sur les forêts et les communautés dépendantes des forêts ne sont pas bien compris du grand public ni des gestionnaires forestiers. Ils considèrent également qu'il existe un niveau relativement élevé d'incertitude rattaché aux effets des changements climatiques, spécialement pour ce qui est des communautés dépendantes des forêts. Ces résultats comportent des grandes implications, dont le renforcement marqué de la sensibilisation portant sur les risques reliés aux changements climatiques et l'accroissement des recherches et des efforts de suivi portant sur la réduction des niveaux d'incertitude rattachés aux conséquences futures au niveau local.

Mots clés : changements climatiques, perception du risque, écosystèmes forestier, communautés dépendantes des forêts

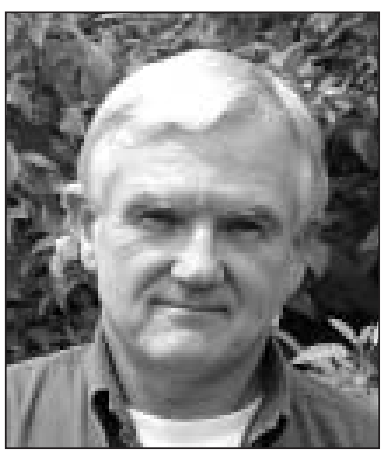

T.B. Williamson

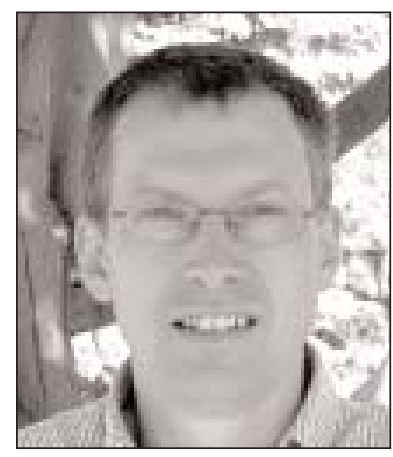

J.R. Parkins

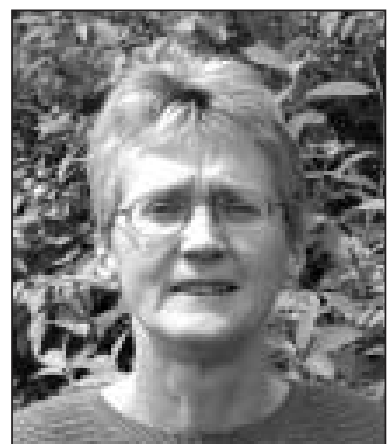

B.L. McFarlane

\section{Introduction}

The level of scientific consensus about climate change is growing. In October 2003 over 1000 U.S. scientists signed a letter sent to the US Senate supporting the findings of earlier reports by the Intergovernmental Panel on Climate Change (2001). The IPCC (2001) report noted that climate change is already underway and that without significant reductions in rates of greenhouse gas emission, global warming will continue.

The prospect of significant global warming is relevant for Canada because northern-forested ecosystems are sensitive to climate change and its related manifestations (Burton and
${ }^{1}$ Natural Resources Canada, Canadian Forest Service, Northern
Forestry Centre, 5320-122 Street, Edmonton, Alberta T6H 3S5. Social Science Research Group - http://nofc.cfs.nrcan.gc.ca/ssrg/ ${ }^{2}$ Corresponding author. E-mail: twilliam@nrcan.gc.ca. 
Cumming 1995, Saporta et al. 1998). Forest-based communities may in turn be impacted due to their strong connections to forested ecosystems (Davidson et al. 2003). The impacts of climate change will vary depending on a combination of a) the magnitude and timing of climate change, $b$ ) the particular characteristics of the systems (biological, economic and social) that are affected (Burton and Cumming 1995, Davidson et al. 2003), and c) the social and economic values at risk (Hauer et al. 2001). Moreover, some types of impacts will have positive effects in some contexts and negative effects in others. It is difficult, therefore, to generalize about the impacts of climate change. However, despite the variability of potential impacts and the uncertainty regarding their overall levels, it is likely that in some locations and for some biological and social systems the impacts of climate change will be negative. It is also possible that the overall net effect on the Canadian forest sector will be negative. Therefore, when viewed at a broad scale, climate change can be viewed as a risk issue (Leiss 2001).

Adaptation can reduce or moderate exposure to the impacts of climate change (Scheraga and Grambsch 1998, Spittlehouse and Stewart 2003). An understanding of the perceptions of risk due to climate change is important for anticipating and assessing actual and potential adaptive responses of particular social groups. Several studies have considered the ecological risks associated with climate change (see, for example, McDaniels et al. 1996, Lazo et al. 2000), but these studies referred to ecosystem risk in general terms. McDaniels et al. (1997) examined perceptions of the risk to water environments posed by a variety of threats including climate change. However, to our knowledge there are no published studies that have specifically investigated perceptions of risk to forest ecosystems and forest-based communities. This study begins to address this gap by examining perceptions of climate change risk to forest ecosystems and forest-based communities held by well-informed, highly educated individuals whose employment is (by and large) tied to the forest sector. To the extent to which these individuals are embedded within key decision-making agencies, an understanding of risk perception among this population will provide insights into their readiness to engage in adaptive strategies.

The remainder of this paper is organized as follows. First, we provide a brief overview of risk perception research on climate change. Second, we describe the methods used to determine the risk perceptions of a sample group of individuals representative of forestry professionals. Third, we present the result of a risk perception questionnaire. Finally, we interpret and discuss the results of the questionnaire as they relate to key themes involving differences between expert and layperson risk perception, scientific uncertainty, and adaptation options.

\section{Risk Perception Research}

Perceptions of risk are both psychological and social constructs. They are formed as a result of personal experiences and by learning processes (Slovic 1987). The psychometric approach has been used to identify several dimensions of risk that have in turn been used to quantify and map risk perception related to climate change and to compare the risk perceptions of experts and the public (McDaniels et al. 1995, 1997; Cavanagh et al. 2000). These dimensions include ecological impact (e.g., species loss and impacts on humans), human benefits and acceptability (e.g., equity of costs and benefits), controllability (e.g., ability to control impacts), and knowledge of impacts (e.g., alternative events or practices). These dimensions underscore the complexity of risk perception and provide a framework for the cognitive characterization of risks associated with climate change. An understanding of the underlying dimensions of these risks and differences among stakeholders is needed for developing communication strategies, understanding diversity in risk perception, influencing behaviour, and designing incentives for mitigating and adapting to risk from climate change (McDaniels et al. 1995, O'Connor et al. 1999).

Social factors are known to influence an individual's risk assessment. Age, sex, education, income, and other demographic characteristics have been found to influence risk perception (Cutter 1993). For example, young people, women, and people with lower levels of education and income tend to be more concerned about hazards (Savage 1993, Davidson and Freudenburg 1996). Although women generally perceive greater risk than men, Lazo et al. (2000) found that men perceived greater overall risk to ecosystems from climate change.

The social groups to which people belong can influence risk perception by amplifying or attenuating individual judgements of risk (Kasperson et al. 2000). People from different social or cultural contexts observe and interpret the world differently. Social groups may vary in terms of their belief systems, norms of behaviour, and judgements of what poses a risk (Dietz et al. 1989). Belonging to a particular social group structures the mindset of members such that they adopt organizational values, beliefs, and norms. For example, people whose work focuses on natural resource management and who must strive to achieve organizational goals are expected to view risk in a manner consistent with organizational (rather than personal) values and their professional interests.

The characteristics or features of risk can also significantly influence perceptions. For example, risks that are unknown or technically complex and that are associated with a high level of dread tend to be more salient than risks that are known and for which levels of dread is lower and controllability is higher (Slovic 1987). At the same time, risk issues that have the potential to become significant may remain dormant with respect to public concern until such time as an accident or other event triggers a reaction (Slovic 1987). Alternatively, other types of risks that are familiar, and not dreaded, and for which individuals feel they are in control of their own level of exposure, may be accepted to a greater degree, even though the probability of an extreme consequence (including death) is relatively high and even though triggering events are relatively common. These kinds of assumed risks are common in sporting and recreational endeavours.

Thus, perceptions of risk of a particular event (e.g., tornado, plane crash), from a particular technology (e.g., nuclear technology), or related to a particular behaviour (e.g., smoking, speeding) can vary widely. Perceptions of any particular risk also vary across society raising the possibility of social conflict. Furthermore, risk perceptions are dynamic and evolve as people become more knowledgeable about the risk and as sensitivity to the risk increases. Levels of trust in the institutions and agencies that manage and control the tech- 
nologies that are possible sources of risk can also influence perceptions of risk (Beamish 2001). In some cases, preconceptions, attitudes, and cognitive limitations in informationprocessing capacity lead individuals and organizations to underestimate or overestimate risk (Khaneman et al. 1982, Clarke 1993, Slovic 2000).

A number of studies have investigated the phenomenon of climate change from a risk perception or social psychological perspective. Fischhoff and Furby (1983) discussed the psychological aspects of climate change and identified a social science research agenda for addressing several key questions, including "Where do subjective judgements enter into scientific analysis?" and "How do people combine multiple and conflicting risks and benefits into a single decision?" Whyte (1985) discussed various features and characteristics of issues like climate change that tend to result in low salience of those issues to lay people including "a) impacts not previously experienced, b) longer time in the future, c) no clear beginning and end, d) indirect effects, e) uncertain/controversial, and f) mechanisms not understood." Other studies have looked at lay perceptions of overall climate change risk. Two general findings have emerged from such studies. First, although global warming is a concern, it is relatively less important than other environmental issues with respect to perceived need for action or adaptive response (e.g., see O'Connor et al. 1999). Second, the public tends to confuse global warming with other global issues such as depletion of the ozone layer (e.g., see Kempton et al. 1995). McDaniels et al. (1997) investigated perceptions of climate change risk to water systems. Although the public ranked climate change risk relatively high in terms of its impact on water systems, they ranked it very low in terms of the need to implement regulatory actions (McDaniels et al. 1997). Experts, on the other hand, perceived climate change as considerably less of a risk to water systems. In contrast, a more recent study (Stedman et al. 2004) found that policy-makers in western Canada ranked the impacts of climate change among the most important resource policy issues.

\section{Methods}

The respondents for this study were participants in the workshop "Climate Change in the Western and Northern Forests of Canada," held in Prince George, BC, in February 2003. The workshop was co-sponsored by the Canadian Climate Impacts and Adaptation Research Network Forest Sector and the McGregor Model Forest. The 139 attendees received the questionnaire before the workshop.

The sample of questionnaire respondents is representative of Canadian forestry professionals with some knowledge of climate change. The average age of respondents was over 40 years (suggesting that they were somewhat experienced), and they were highly educated. Also, each was motivated to voluntarily attend a workshop specific to climate change and forestry issues. Most respondents were employed in provincial management agencies or in research agencies. Therefore, we believe that these respondents represent people with an above-average interest in climate change and above average understanding of its potential ramifications for forests and forest-based communities.

Perceived risk to forest ecosystems was assessed by means of a subset of scales previously identified as relevant to climate change (McDaniels et al. 1997, Lazo et al. 2000, Stedman et al. 2004). Because of concerns about response burden, we reduced the number of scales from the original 31 in McDaniels et al. (1997). Ten scales were selected and re-worded to assess perceptions of the impacts, certainty, controllability, predictability, adaptability, "noticeability," acceptability, and knowledge of these impacts. Each scale was assessed on the basis of a seven-point rating. A similar set of 12 scales was used to assess perceived risk to forest-based communities, including an assessment of general risk to forest-based communities.

In addition to perceptions of risk, eight statements (rated on a seven-point scale ranging from $1=$ strongly disagree to $7=$ strongly agree) were used to assess general beliefs about climate change. Social influences were assessed according to age, sex, level of education, place of residence, and type of employer.

\section{Results}

The completed questionnaires were collected during on-site registration at the workshop. A total of 53 attendees completed the questionnaire (38\% response rate). Seventy one percent of survey respondents were from British Columbia. Employees of provincial governments accounted for $42 \%$ of respondents while universities and the federal government accounted for $19 \%$ and $13 \%$ of respondents, respectively. Ninety-eight percent of respondents have at least a Bachelors degree ( $49 \%$ have a graduate degree). The mean age is 42 years and $40 \%$ were female.

Table 1 summarizes the responses to general beliefs about climate change. Respondents generally agreed (mean $>4.0$ ) that human activities are a major cause of climate change and disagreed (mean $<4.0$ ) with statements that the impacts are exaggerated and that there is ample time to adapt. These results suggest that this group viewed climate change as a real and immediate risk caused by human activities. Thus, they may support actions and policies directed at immediate adaptation to climate change impacts. There is some uncertainty, however, regarding the extent to which respondents felt that climate change poses a serious threat to them personally. Although respondents indicated that they were not personally prepared for impacts (mean rating 3.22), they did not view climate change as a threat to them and their families (mean rating 3.92, near the midpoint).

Table 2 summarizes responses to questions about perceived risks to forest ecosystems. Respondents perceived climate change as currently having a significant impact (mean 5.32) and they indicated that climate change would continue to have a significant impact on forest ecosystems within the next 50 years (mean 5.96). They perceived that these effects would be noticeable, and that they are neither acceptable, controllable, nor predictable. The degree to which respondents felt that forest ecosystems would be able to adapt to climate change approached the midpoint value (mean 3.64). Moreover, the standard deviation for this question was relatively high, suggesting greater disagreement among respondents. In contrast, one of the strongest areas of agreement among respondents was the degree to which they are of the view that the effects of climate change on forest ecosystems are understood: they ranked perceived level of understanding by both the public and forest managers as low (mean 1.54 and 2.40). 


\begin{tabular}{lll}
\hline Statement & Mean & Standard deviation \\
\hline Human activities are a major cause of climate change. & 5.54 & 1.69 \\
All climate change impacts are negative. & 2.71 & 1.33 \\
Climate change impacts are exaggerated. & 3.81 & 1.40 \\
Generally, the science of climate change is inconclusive. & 3.92 & 3.22 \\
Climate change is a serious threat to my family and me. & 3.22 & 1.59 \\
I do not understand the impacts of climate change. & 2.85 & 1.62 \\
I feel that my family and I are well prepared for climate change impacts. & 1.43 \\
There is ample time to adapt to climate change. & & 1.45 \\
\hline
\end{tabular}

${ }^{1}$ Rated on a scale from 1 to 7 , where $1=$ strongly disagree and $7=$ strongly agree.

Table 2. Perceptions of climate change as a risk to forest ecosystems

\begin{tabular}{|c|c|c|c|}
\hline $\begin{array}{l}\text { Perception } \\
\text { "Please indicate the degree to which:" }\end{array}$ & $\begin{array}{l}\text { Ratings } \\
\text { (1 to } 7)\end{array}$ & Mean & $\begin{array}{l}\text { Standard } \\
\text { deviation }\end{array}$ \\
\hline $\begin{array}{l}\text { You agree that climate change is currently having } \\
\text { a significant impact on forest ecosystems. }\end{array}$ & Strongly disagree to strongly agree & 5.32 & 1.37 \\
\hline $\begin{array}{l}\text { You agree that within the next } 50 \text { years climate change } \\
\text { is going to have a significant impact on forest ecosystems. }\end{array}$ & Strongly disagree to strongly agree & 5.96 & 1.19 \\
\hline $\begin{array}{l}\text { You feel that there is certainty about the effects of climate } \\
\text { change on the sustainability of forest ecosystems. }\end{array}$ & Low certainty to significant certainty & 3.41 & 1.50 \\
\hline $\begin{array}{l}\text { You feel that forest managers have the ability to control } \\
\text { climate change impacts on forest ecosystems. }\end{array}$ & Not controllable to very controllable & 2.64 & 1.24 \\
\hline $\begin{array}{l}\text { Climate change effects on forest ecosystems } \\
\text { are predictable. }\end{array}$ & Not predictable to very predictable & 2.94 & 1.35 \\
\hline $\begin{array}{l}\text { You agree that Canada's forests will evolve and } \\
\text { adapt in pace with climate change. }\end{array}$ & Strongly disagree to strongly agree & 3.64 & 1.74 \\
\hline $\begin{array}{l}\text { You expect that the effects of climate change on forest } \\
\text { ecosystems will be noticeable. }\end{array}$ & Not noticeable to very noticeable & 5.79 & 0.80 \\
\hline $\begin{array}{l}\text { Anticipated climate change impacts on forest ecosystems } \\
\text { are acceptable to you personally. }\end{array}$ & Not acceptable to very acceptable & 3.25 & 1.64 \\
\hline $\begin{array}{l}\text { You feel that the effects of climate change on forest } \\
\text { ecosystems are understood by the general public. }\end{array}$ & Not well understood to well understood & 1.54 & 0.99 \\
\hline $\begin{array}{l}\text { You feel that the effects of climate change on forest } \\
\text { ecosystems are understood by forest managers. }\end{array}$ & Not well understood to well understood & 2.40 & 1.02 \\
\hline
\end{tabular}

Table 3 summarizes responses to questions about perceived risks to forest-based communities. Respondents perceived that climate change poses a moderate threat to forestbased communities (mean value 3.23 ) and that community well-being will be somewhat affected (mean value 4.78). Ratings for the degree to which respondents felt that climate impacts are controllable and that communities have the capacity to adapt were near the midpoint. These results are consistent with the perception of significant scientific uncertainty about the impacts of climate change on communities (mean 5.10). Respondents were in strong agreement (i.e., low standard deviation) that one of the main impacts of climate change would be higher levels of uncertainty for industries located in forest-based communities (mean value 4.9). Similar to the situation for ecosystem risk, the respondents felt that the effect of climate change on forest-based communities is not well understood by the general public or policymakers (mean 1.55 and 2.00).
One of the unique aspects of this study was its characterization of perceived risk to both ecosystems and social systems. Table 4 summarizes the response scores for seven features of climate risk (note that for "impact" and "adaptive capacity" the wording was not exactly the same). Perceived risks to forest ecosystems and communities were similar, but some differences are suggested. Respondents tended to view climate change as having more significant future impacts on ecosystems than on forest-based communities and they viewed the impacts as less controllable, somewhat less predictable, and slightly more noticeable for forested ecosystems. This suggests that perceived risks to ecosystems are higher than perceived risks to communities.

\section{Discussion and Conclusions}

One significant question in studies of risk perception related to climate change concerns the extent to which perceptions of risks diverge between experts and lay people. Lazo et al. 
Table 3. Perceptions of climate change as a risk to forest-based communities

\begin{tabular}{|c|c|c|c|}
\hline $\begin{array}{l}\text { Perception } \\
\text { "Please indicate the degree to which:" }\end{array}$ & $\begin{array}{l}\text { Ratings } \\
(1 \text { to } 7)\end{array}$ & Mean & $\begin{array}{r}\text { Standard } \\
\text { deviation }\end{array}$ \\
\hline $\begin{array}{l}\text { You agree with the statement "climate change is a serious } \\
\text { threat to forest-based communities." }\end{array}$ & Strongly agree to strongly disagree & 3.23 & 1.65 \\
\hline $\begin{array}{l}\text { Impact of climate change on community } \\
\text { well-being will be significant. }\end{array}$ & Not significant to significant & 4.78 & 1.42 \\
\hline $\begin{array}{l}\text { You feel that climate change impacts on forest-based } \\
\text { communities are controllable through planning } \\
\text { and preparation. }\end{array}$ & Not controllable to very controllable & 3.94 & 1.28 \\
\hline $\begin{array}{l}\text { You feel that forest-based communities have the capacity } \\
\text { to adapt to climate change impacts. }\end{array}$ & Low capacity to significant capacity & 3.62 & 1.47 \\
\hline $\begin{array}{l}\text { Climate change effects on the well-being of communities } \\
\text { are predictable. }\end{array}$ & Not predictable to very predictable & 3.17 & 1.34 \\
\hline $\begin{array}{l}\text { You expect that the effects of climate change on } \\
\text { forest-based communities will be noticeable. }\end{array}$ & Not noticeable to very noticeable & 5.35 & 0.97 \\
\hline $\begin{array}{l}\text { Anticipated climate change impacts on forest-based } \\
\text { communities are acceptable to you personally. }\end{array}$ & Not acceptable to very acceptable & 3.18 & 1.40 \\
\hline $\begin{array}{l}\text { You feel that there is scientific uncertainty about the } \\
\text { effects of climate change on communities. }\end{array}$ & No uncertainty to significant uncertainty & 5.10 & 1.36 \\
\hline $\begin{array}{l}\text { You feel that the effects of climate change on forest-based } \\
\text { communities are understood by the general public. }\end{array}$ & Not well understood to well understood & 1.55 & 0.69 \\
\hline $\begin{array}{l}\text { You feel that the effects of climate change on forest-based } \\
\text { communities are understood by policy makers. }\end{array}$ & Not well understood to well understood & 2.00 & 0.81 \\
\hline $\begin{array}{l}\text { You feel that climate change will present opportunities to } \\
\text { improve well-being in forest-based communities. }\end{array}$ & No benefits to significant benefits & 3.75 & 1.23 \\
\hline $\begin{array}{l}\text { You feel that climate change will lead to higher levels of } \\
\text { economic uncertainty for businesses and firms in } \\
\text { forest-based communities. }\end{array}$ & $\begin{array}{l}\text { No effects on uncertainty to significant } \\
\text { increase in uncertainty }\end{array}$ & 4.87 & 1.17 \\
\hline
\end{tabular}

Table 4. Comparison of mean responses for forested ecosystems and forest-based communities

\begin{tabular}{lcc}
\hline Feature & $\begin{array}{c}\text { Ecosystems } \\
\text { ratings } \\
(1-7)\end{array}$ & $\begin{array}{c}\text { Communities } \\
\text { ratings } \\
(1-7)\end{array}$ \\
\hline Impact & 5.96 & 4.78 \\
Controllability & 2.64 & 3.94 \\
Predictability & 2.94 & 3.17 \\
Adaptive capacity & 3.64 & 3.62 \\
Noticeable & 5.79 & 5.35 \\
Acceptability & 3.25 & 3.18 \\
Perception of layperson's & & \\
$\quad$ understanding & 1.54 & 1.55 \\
\hline
\end{tabular}

(2000), for example, found that experts perceived the impacts of global climate change lower and more acceptable relative to lay people. However, these authors also concluded that the overall level of concern within both groups was relatively low. They noted that: "This finding is consistent with numerous public opinion polls showing relatively little public concern about global climate change compared with other societal issues." MacDaniels et al. (1997) also found that lay people ranked global climate change as a greater potential risk than experts. If experts do have lower perception of the risks of global climate change then experts and regulatory agencies may be an oppositional force to the need and (or) desire of the public to take action to reduce that risk. However, in our study (with a sample consisting mainly of researchers and government employees) there was no indication that experts would be resistant to policy initiatives to prepare for, adapt to, or mitigate climate change. These experts recognized that climate change is caused by humans, they felt that some immediate action may be necessary, they recognized that climate change is having a significant impact on both forested ecosystems and forest-based communities (and that these impacts will continue in the future), and they felt that the impacts on ecosystems and communities tended toward being unacceptable. A recent study by Stedman et al. (2004) reinforces these findings.

At the same time, previous studies of lay perceptions of climate risk have suggested that although the risk is viewed as important, it is not particularly salient relative to other types of risk (for example, see Whyte 1985). Davidson et al. (2003) explored this further and identified a number of socio-cultural, political, and economic features of forest-based communities that may contribute to the tendency for climate risks to have low salience. The respondents in our survey also strongly believed that the effects of climate change on forest ecosystems and communities are not well understood by the general public, policy-makers and forest managers. The main 
implication is that rather than technical experts being opposed to preparing for, adapting to, and mitigating climate and climate change, it may be forest stakeholders, residents of forest-based communities, and forest managers who hesitate to take action or resist policies promoting adaptation (notethis is a general statement and it does not necessarily apply to all communities nor does it necessarily apply to all segments of particular communities). This has important implications for climate change strategies and policies. First, there is a need for more effective communication of climate change risks. The Canadian Climate Impacts and Adaptation Research Network and the Canadian Model Forest Network are beginning this process. However, a more substantive, coordinated, and structured approach to raising awareness of climate change risks and communicating strategies may be necessary.

Another general theme relates to uncertainty as a defining feature of climate change (Duinker 1990). The respondents in this study expressed moderate uncertainty about the effects of climate change on forest ecosystems and significant uncertainty about the effects of climate change on forest-based communities. They also felt that climate change would lead to higher levels of economic uncertainty for businesses in forestbased communities. An important component of any climate change strategy should include measures to address this uncertainty. Increased efforts to reduce the uncertainty related to the impacts of climate and climate change would likely not be opposed-particularly if those efforts were targeted to reducing uncertainties associated with impacts on social systems and groups with close ties to forests.

These perceptions of uncertainty in forest-based communities mark a key area of distinction within these results. Although there are some strong similarities in respondent's thinking related to uncertainty within ecosystems and communities under future climate regimes, one of the key differences between these two contexts involves perceptions of impacts and the controllability of those impacts. Respondents suggested that impacts in forest-based communities would be lower than in forest ecosystems and that those impacts would be more controllable in the communities. These results suggest that respondents are observing or sensing factors at play in communities that are not present within forest ecosystems. These perspectives relate to a growing interest within the climate change literature to identify specific adaptive potentials within human systems that are in some ways entirely unique or qualitatively distinct from adaptive potentials within biological systems.

Some of the processes associated with adaptation are similar for ecosystems and communities. Adaptive ecosystems benefit from more diverse structure and species composition. Similarly, social scientists consistently identify economic diversity as a key feature of adaptive communities (MacKendrick and Parkins 2004). Given the prevalence of single-industry towns across Canada, this key feature of adaptive communities is of particular concern. Accordingly, Davidson et al. (2003) suggested that a key deficit within forest-based communities is over adaptation of local human resources to a single industry. If communities can begin to diversify their economies and rely on several key economic drivers, then they will be better positioned to absorb future climate change impacts.
At a more basic level, the adaptive uniqueness within forest-based communities (relative to forest ecosystems) is the presence of human agency-actions, systematic acquisition of new information, preparation, and planning. These qualities will have a significant bearing on community-level impacts of climate change. To the extent that political systems and resources can be mobilized, economic systems adjusted, and expected and unexpected shocks associated with climaterelated events absorbed by social systems, human agency can have important implications for the future controllability of climate impacts. Insights such as these are likely at the root of the differential responses to questions about impacts and controllability in this study.

Several climate change strategies and policy responses can flow from this analysis. First, social science researchers are beginning to understand the dynamics of community vulnerability to climate change. This involves an understanding of both the exposure of forest-based communities to climate change and the capacity of communities to adapt (Adger et al. 2004). It also involves an understanding of factors that may influence willingness to adapt. On the basis of this analysis, vulnerable communities can be identified and a more precise understanding of the nature of that vulnerability determined. Second, vulnerability assessments may demand some response in terms of provision of information and or programs. In some cases, vulnerability will be associated with heavy reliance on a single industry or source of natural capital that is threatened by climate change. In other cases, economic systems and sources of natural capital may be of less concern than political systems.

This study provides some preliminary information on the perceptions of researchers and government experts about the risk to forest ecosystems and forest-based communities posed by climate change. A better understanding of the risk constructs of researchers and government experts may provide some indication of institutional behaviours, attitudes, and perspectives. As noted, the respondents to this survey acknowledged several key aspects of climate change. They perceived that significant impacts are likely, and they realized that human activities are a causal factor in global warming. This type of group is therefore more likely to be a catalyst for change rather than an oppositional force. The degree of support, of course, will depend on the nature of the changes proposed. Efforts to raise awareness and reduce uncertainty would likely be supported. However, this study was limited to a small sample of experts primarily from British Columbia. To determine if these results are representative of a larger population, the study should be repeated with forestry experts from other areas in Canada.

\section{Acknowledgements}

We thank Greg McKinnon and Shelly Webber of the Canadian Climate Impacts and Adaptation Research Network Forest Sector and Kelvin Hirsch of the Canadian Forest Service for their assistance with this study. We also thank Harry Archibald and Adam Wellstead for providing comments on the paper. 


\section{References}

Adger, W.N., N. Brooks, G. Bentham, M. Agnew and S. Eriksen. 2004. New indicators of vulnerability and adaptive capacity. Tyndall Centre for Climate Research, Technical Report Number 7. Tyndall, UK. 122 p.

Beamish, T. 2001. Environmental hazard and institutional betrayal. Orgon. Environ. 14: 5-33.

Burton, P.J. and S.G. Cumming. 1995. Potential effects of climatic change on some western Canadian forests, based on phenological enhancements to a patch model of forest succession. Water Air Soil Pollut. 82: 401-414.

Cavanagh, N., T. McDaniels, L. Axelrod and P. Slovic. 2000. Perceived ecological risks to water environments from selected forest industry activities. For. Sci. 46(3): 344-355.

Clarke, L. 1993. The disqualification heuristic: when do organizations misperceive risk? Res. Soc. Probl. Public Policy 1: 289-312.

Cutter, S.L. 1993. Living with risk: the geography of technical hazards. Edward Arnold, London, UK.

Davidson, D. and W. Freudenburg. 1996. Gender and environmental risk concerns: a review and analysis of available research. Environ. Behav. 28(3): 302-339.

Davidson, D.J., T.B. Williamson and J.R. Parkins. 2003. Understanding climate change risk and vulnerability in northern forest-based communities. Can. J. For. Res. 33: 2252-2261.

Dietz, T., P.C. Stern and R.W. Rycroft. 1989. Definitions of conflict and legitimation of resources: the case of environmental risk. Sociol. For. 4(1): 47-70.

Duinker, P. 1990. Climate change and forest management, policy and land use. Land Use Policy 7: 124-137.

Fischhoff, B. and L. Furby. 1983. Psychological dimensions of climatic change. In R.S. Chen and S.H. Schneider (eds.). Social science research and climate change: an interdisciplinary appraisal. D. Reidal Publishing. Co., Dordrecht, Holland.

Hauer, G., T.B. Williamson and M. Renner. 2001. Socioeconomic impacts and adaptive responses to climate change: a Canadian forest sector perspective. Natural Resources Canada, Canadian Forest Service, Northern Forestry Centre, Edmonton, Alberta. Inf. Rep. NOR-X-373. 55 p.

Intergovernmental Panel on Climate Change (IPCC). 2001. Climate change 2001: the scientific basis. Cambridge University Press, Cambridge, UK.

Kasperson, R.E., O. Renn, P. Slovic, H.S. Brown, J. Emel, R. Goble, J. Kasperson and S. Ratick. 2000. The social amplification of risk: a conceptual framework. In P. Slovic (ed.). The perception of risk. Earthscan Publications Ltd., London, UK.
Kempton, W., J.S. Boster and J.A. Hartley. 1995. Environmental values in American culture. MIT Press, Cambridge, Mass.

Khaneman, D., P. Slovic and A. Tversky. 1982. Judgement under uncertainty: heuristics and biases. Cambridge University Press, Cambridge, UK.

Lazo, J.K., J.C. Kinnell and A. Fisher. 2000. Expert and layperson perceptions of ecosystem risk. Risk Anal. 20(2): 179-193.

Leiss, W. 2001. In the chamber of risks. McGill-Queen's University Press, Montreal, Quebec.

MacKendrick, N.A. and J.R. Parkins. 2004. Frameworks for assessing community sustainability: a synthesis of current research in British Columbia. Natural Resources Canada, Canadian Forest Service, Northern Forestry Centre, Edmonton, AB, Inf. Rep. NOR$\mathrm{X}-392.18 \mathrm{p}$

McDaniels, T., L.J. Axelrod, N.S. Cavanagh and P. Slovic. 1997. Perception of ecological risk to water environments. Risk Anal. 17(3): 341-352.

McDaniels, T., L.J. Axelrod and P. Slovic. 1995. Characterizing perception of ecological risk. Risk Anal. 15(5): 575-588.

McDaniels, T., L.J. Axelrod and P. Slovic. 1996. Perceived ecological risks of global change: a psychometric comparison of causes and consequences. Global Environ. Change 6(2): 159-171.

O'Connor, R.E., R.J. Bord and A. Fisher. 1999. Risk perceptions, general environmental beliefs, and willingness to address climate change. Risk Anal. 19: 461-471.

Saporta, R.; J.R. Malcolm and D.L. Martell. 1998. The impact of climate change on Canadian forests. In G. Koshida and W. Avis (eds.). The Canada country study: climate impacts and adaptations. Vol. 7. National sectoral volume. pp. 319-382. Environment Canada, Environmental Adaptation Research Group, Toronto, Ontario.

Savage, I. 1993. Demographic influences on risk perceptions. Risk Anal. 13(4): 413-420.

Scheraga, J.D. and A.E. Grambsch. 1998. Risks, opportunities, and adaptation to climate change. Climate Res. 10: 85-95.

Slovic, P. 1987. Perception of risk. Science 236: 280-285.

Slovic, P. 2000. The perception of risk. Earthscan Publications Ltd., London.

Spittlehouse, D.L. and R.B. Stewart. 2003. Adaptation to climate change in forest management. B.C. J. Ecosyst. Manage. 4(1): 1-11.

Stedman, R.C., D. Davidson and A. Wellstead. 2004. Risk and climate change: Perceptions of key policy actors in Canada. Risk Anal. 24(5): 1393-1404.

Whyte, A.V.T. 1985. Perception. in R.W. Kates, J.H. Ausubel and M. Berberian (eds.). Climate impact assessment. John Wiley and Sons, New York. 